\title{
Inhibition of autophagy flux by sertraline attenuates TRAIL resistance in lung cancer via death receptor 5 upregulation
}

\author{
KAZI MOHAMMAD ALI ZINNAH ${ }^{1,2}$, JAE-WON SEOL ${ }^{1}$ and SANG-YOUEL PARK ${ }^{1}$ \\ ${ }^{1}$ Biosafety Research Institute, College of Veterinary Medicine, Jeonbuk National University, Iksan, Jeonbuk 54596, \\ Republic of Korea; ${ }^{2}$ Department of Animal and Fish Biotechnology, Faculty of Biotechnology and \\ Genetic Engineering, Sylhet Agricultural University, Sylhet 3100, Bangladesh
}

Received November 19, 2019; Accepted May 8, 2020

DOI: $10.3892 /$ ijmm.2020.4635

\begin{abstract}
Tumor necrosis factor-related apoptosis-inducing ligand (TRAIL) is a potential target for cancer therapy, owing to its ability to selectively kill cancer cells without causing significant toxicity to normal cells. However, due to the lack of death receptor expression, cancer cells can become highly resistant to TRAIL. Hence, it is vital to develop agents that restore TRAIL efficacy. Sertraline is an antidepressant drug with anticancer properties. To the best of our knowledge, this is the first study to demonstrate that sertraline inhibits autophagic flux and increases the expression of death receptor 5 (DR5) on TRAIL-resistant lung cancer cells. Inhibition of autophagy using autophagy inhibitors 3-methyladenine and chloroquine upregulated the expression of DR5 and enhanced TRAIL-induced apoptosis, as confirmed by the increase of pro-apoptotic proteins caspase- 8 and caspase-3. Silencing DR5 expression using DR5 small interfering RNA prevented sertraline-induced TRAIL-mediated apoptosis, indicating the role of DR5 in TRAIL-mediated apoptosis. Overall, sertraline enhanced TRAIL-mediated apoptosis via the downregulation of AMP-activated protein kinase phosphorylation, resulting in the inhibition of autophagic flux, upregulation of DR5 expression, and activation of the apoptotic caspase cascade. These data suggested that sertraline could be used to sensitize human lung cancer cells to TRAIL, while also serving as a therapeutic option in cancer patients with depression.
\end{abstract}

\section{Introduction}

Lung cancer is one of the most common types of cancer and a leading cause of death worldwide (1). After the diagnosis

Correspondence to: Professor Sang-Youel Park, Department of Veterinary Medicine, Biosafety Research Institute, College of Veterinary Medicine, Jeonbuk National University, 79 Gobong-ro, Iksan, Jeonbuk 54596, Republic of Korea

E-mail: sypark@chonbuk.ac.kr

Key words: sertraline, tumor necrosis factor-related apoptosis-inducing ligand, death receptor-5, apoptosis, autophagy of lung cancer at stage 3 or 4, the 5-year survival rate is $\sim 15 \%$ (2). Cancer research and clinical trials are in progress for the development of a suitable treatment $(3,4)$. At present, the primary treatment regimens employed include surgery, radiotherapy, chemotherapy, or various combinations of the three. Combination therapy may prevent the development of advanced progressive tumors that are resistant to monotherapy, and has played a significant role in cancer management for several years. In addition, combination strategies with effective chemotherapeutic drugs may offer advantages against cancers such as non-small cell lung adenocarcinoma (5-7).

Tumor necrosis factor-related apoptosis-inducing ligand (TRAIL) is a commonly known transmembrane cytokine that selectively kills cancer cells by binding to death receptors, while also being non-toxic to normal cells $(8,9)$. Cancer cells are often resistant to TRAIL due to their insufficient expression of death receptors (DR4/DR5), excessive expression of decoy receptors, or genetic and epigenetic modification of TRAIL receptors (10). The binding of TRAIL to death receptors results in the induction of the apoptotic pathway to activate apoptotic signals (11). TRAIL binds to its receptors, DR4 and DR5, and forms death-inducing signaling complexes (DISC), which in association with adaptor molecules, such as Fas-associated protein with death domain and caspase-8, activate caspase-9, and consequently activate caspase- 3 to ensure apoptotic cell death $(12,13)$. Several types of cancer cells, including lung A549 cells, are resistant to the apoptotic effects of TRAIL (14). However, TRAIL resistance can be prevented through the effective use of TRAIL-sensitizing pharmacological agents $(15,16)$.

Autophagy is an intracellular catabolic mechanism associated with a well-maintained self-degrading lysosomal pathway. It is vital to maintain programmed cell death and cellular homeostasis. In this process, cytosolic substances are sequestered into autophagosomes that fuse with lysosomes to form autolysosomes, wherein their substances are degraded (17). The process of autophagosome formation is associated with the autophagy-related gene (Atg)12-Atg5-Atg16 complex and the conversion of microtubule-associated protein 1 light chain 3 (LC3)-I isoform to an autophagosome-associated LC3-II, which commonly serves as an autophagy marker (18). A well-known autophagy marker, sequestosome 1 (p62), can be integrated into autophagosomes upon direct interaction 
with LC3. Autophagic flux inhibition may result in increased levels of cellular p62 due to the inhibition of lysosomal degradation (19). Inhibiting autophagy may have several effects, including sensitizing cancer cells to chemotherapy and conventional radiotherapy treatment (20), and serving as an effective strategy for cancer management. Chloroquine and 3-methyladenine (3-MA) are commonly used autophagy inhibitors in the study of autophagy. Chloroquine inhibits lysosome acidification and prevents the fusion of autophagosomes with lysosomes (21). The compound 3-MA is a specific inhibitor of phosphoinositide 3-kinase (PI3K) and autophagy (22). AMP-activated protein kinase (AMPK), a key conserved sensor, maintains the energy balance to regulate cellular energy homeostasis. Autophagic flux formation involves the activation of AMPK via the inhibition of mammalian target of rapamycin (mTOR) under cellular stress. A number of studies have reported that the downregulation of AMPK phosphorylation mediates anticancer effects and autophagy plays a protective function as an anticancer mechanism $(23,24)$. Inhibition of AMPK phosphorylation can result in cellular stress and apoptosis induction by downregulating autophagy (25).

Selective serotonin reuptake inhibitors (SSRIs) are commonly used to treat depression, anxiety and some social behavioral disorders, and are often suggested for the treatment of depression in patients with cancer $(26,27)$. Sertraline is an SSRI that is broadly used as an antidepressant drug and exerts antitumor activities against various types of cancers, including colorectal cancer, liver cancer and lymphoma (28). In the present study, the use of sertraline as a sensitizing agent to TRAIL-mediated apoptosis in lung cancer cells was investigated and the molecular mechanisms underlying the anticancer effects of sertraline in combination with TRAIL were explored. It was found that this effect was mediated through the inhibition of autophagy via downregulation of AMPK phosphorylation and activation of DR5, indicative of the effective sensitization of TRAIL-resistant lung cancer cells.

\section{Materials and methods}

Cell culture. A549 and HCC-15 cells originating from lung tumors were obtained from the American Type Culture Collection. Calu-3 cancer cells were purchased from the Korean Cell Line Bank (Korean Cell Line Research Foundation). Roswell Park Memorial Institute (RPMI)-1640 cell culture media (Gibco; Thermo Fisher Scientific, Inc.) supplemented with $10 \%$ (v/v) fetal bovine serum (Atlas Biologicals, Inc.) and $100 \mu \mathrm{g} / \mathrm{ml}$ penicillin-streptomycin were used for cell culture at $37^{\circ} \mathrm{C}$ in $5 \% \mathrm{CO}_{2}$.

Reagents. Sertraline was procured from Cayman Chemical Company. Chloroquine $(10 \mu \mathrm{M})$ and 3-MA (5 mM) were obtained from Sigma-Aldrich (Merck KGaA), and TRAIL $(100 \mathrm{ng} / \mathrm{ml})$ was purchased from AFrontier Co., Ltd.

Cell viability assay. A549, HCC-15 and Calu-3 cells were seeded into 12 -well plates at a density of $1 \times 10^{4}$ cells and incubated at $37^{\circ} \mathrm{C}$ for $24 \mathrm{~h}$. Cultured cells were pretreated with sertraline at different concentrations $(0,2.5,5$ and $10 \mu \mathrm{M})$ for $18 \mathrm{~h}$, and then treated with recombinant TRAIL $(100 \mathrm{ng} / \mathrm{ml})$ for $2 \mathrm{~h}$ and $30 \mathrm{~min}$. Some cells were also preincubated with chloroquine $(10 \mu \mathrm{M})$ or 3 -MA $(5 \mathrm{mM})$ for $18 \mathrm{~h}$, and then treated with or without recombinant TRAIL $(100 \mathrm{ng} / \mathrm{ml})$ for $2 \mathrm{~h} 30 \mathrm{~min}$. Cell morphology was observed under an inverted microscope (Nikon Corporation). Crystal violet staining was used for the assessment of cell viability. In this method, viable cells were stained with a crystal violet staining solution ( $0.5 \%$ crystal violet in $30 \%$ ethanol and $3 \%$ formaldehyde) for 10-15 min at room temperature, washed 3-4 times with phosphate-buffered saline (PBS), and dried. Viability of cells was also assessed by an MTT assay. In brief, $350 \mu 1$ of $5 \mathrm{mg} / \mathrm{ml}$ MTT solution was added to each well and the plate was incubated at $37^{\circ} \mathrm{C}$ for $2 \mathrm{~h}$ and $30 \mathrm{~min}$. The medium was removed and $500 \mu \mathrm{l}$ DMSO was added to each well. The absorbance was recorded at $570 \mathrm{~nm}$ wavelength using a spectrophotometer (Bio-Rad Laboratories, Inc.). All experiments were performed at least three times. Viability was expressed relative to the percentage of the control group, which was set to $100 \%$.

Lactate dehydrogenase $(\mathrm{LDH})$ assay. Cell culture supernatants were collected and cytotoxicity was analyzed using an LDH detection kit (cat. no. MK401; Takara Bio, Inc.) according to the manufacturer's protocol. LDH was assessed by measuring absorbance at $490 \mathrm{~nm}$ wavelength using a microplate reader (Spectra Max M2; Molecular Devices, LLC).

Western blot analysis. Cultured A549 cells were washed with $1 \mathrm{X}$ cold PBS, harvested with a lysis buffer $25 \mathrm{mM}$ HEPES (pH 7.4), $100 \mathrm{mM}$ ethylenediaminetetraacetic acid (EDTA), $5 \mathrm{mM}$ magnesium chloride $\left(\mathrm{MgCl}_{2}\right), 0.1 \mathrm{mM}$ dithiothreitol (DTT) and protease inhibitor cocktail], sonicated to obtain cell lysates (4 sec/20 kHz) and centrifuged at 11,200 x g for $10 \mathrm{~min}$ at $4^{\circ} \mathrm{C}$. The protein concentration was assessed using a BCA protein assay kit (Thermo Fisher Scientific, Inc.). The cell supernatant was collected and the proteins $(30 \mu \mathrm{g})$ were separated by SDS-PAGE on 10-15\% gels. The separated protein bands were transferred to nitrocellulose or PVDF membranes, which were blocked with $5 \%$ non-fat dried milk at $25^{\circ} \mathrm{C}$ for 1 to $2 \mathrm{~h}$. Next, specific primary antibodies in a dilution buffer [1\% milk and 1\% PBS with 1\% Tween-20 (PBST)] for $1 \mathrm{~h}$ at $25^{\circ} \mathrm{C}$. The following primary antibodies were used for immunoblotting: LC3 (1:1,000; cat. no. 4108), p62 (1:1,000; cat. no. 5114s), cleaved caspase-3 (1:1,000; cat. no. 39665), AMPK (1:1,000; cat. no. 2532), phosphorylated (p)-AMPK $\alpha$ (1:1,000; cat. no. 2535), mTOR (1:1,000; cat. no. 2983) and p-mTOR (1:1,000; cat. no. 5536; all from Cell Signaling Technology, Inc.); cleaved caspase-8 (1:1,000; cat. no. 551242; BD Pharmingen); DR5 (1:10,000; cat. no. ab181846) and DR4 $(1: 1,000$; cat. no. ab8414; both from Abcam); and $\beta$-actin (1:1,000; cat. no. A5441; Sigma-Aldrich; Merck KGaA). Then, membranes were probed with horseradish peroxidase-conjugated secondary antibodies (1:5,000; cat. nos. ADI-SAB-100 and ADI-SAB-300; Enzo Life Sciences, Inc.) at $25^{\circ} \mathrm{C}$ for $1 \mathrm{~h}$. The targeted protein bands were detected with enhanced chemiluminescence reagents (Cytvia). Bands were visualized using a Fusion-FX7 image capturing system (Vilber Lourmat).

Immunocytochemistry (ICC). A549 cells ( $1 \times 10^{5}$ cells/well) were cultured on glass coverslips at $37^{\circ} \mathrm{C}$ for $24 \mathrm{~h}$ and treated with sertraline for $18 \mathrm{~h}$, followed by washing with $1 \%$ PBS and 
fixing with $4 \%$ paraformaldehyde in PBS at room temperature for $15 \mathrm{~min}$. Cells were washed twice with ice-cold PBS and incubated with PBS containing $0.25 \%$ Triton X-100 at room temperature for $10 \mathrm{~min}$. After incubation, cells were washed three times with PBS and blocked with $1 \%$ bovine serum albumin (BSA; GenDEPOT) in PBST for $30 \mathrm{~min}$ at $4^{\circ} \mathrm{C}$. Cells were probed with primary antibodies [anti-p62 (1:100; cat. no. 5114s; Cell Signaling Technology, Inc.) and anti-DR5 (1:100; cat. no. ab181846; Abcam) diluted in PBST containing $1 \% \mathrm{BSA}]$ in a $5 \% \mathrm{CO}_{2}$ incubator at $37^{\circ} \mathrm{C}$ for $3 \mathrm{~h}$, followed by washing three times with PBS. These cells were then incubated with the Alexa Fluor ${ }^{\circledR}$ 488-conjugated donkey polyclonal anti-rabbit secondary antibody (1:1,000; cat. no. A-21206; Thermo Fisher Scientific, Inc.) for $2 \mathrm{~h}$ at $25^{\circ} \mathrm{C}$ in a dark condition. The solution was washed off and cells were further washed 3-4 times with PBS and stained with DAPI for $10 \mathrm{~min}$ at room temperature $\left(25^{\circ} \mathrm{C}\right)$. Cells were washed three times and mounted with a fluorescent mounting medium. Images were captured using a fluorescence microscope (Nikon ECLIPSE 80i; Nikon Corporation) at x400 magnification.

Transmission electron microscopy (TEM). Adherent A549 cells $\left(1 \times 10^{6}\right.$ cells/well) were detached using trypsin and then fixed with $2 \%$ glutaraldehyde (Electron Microscopy Sciences) and $2 \%$ paraformaldehyde in $0.05 \mathrm{M}$ sodium cacodylate buffer ( $\mathrm{pH} 7.2$; Electron Microscopy Sciences) for $2 \mathrm{~h}$ at $4^{\circ} \mathrm{C}$. Next, cells were treated with $2 \%$ osmium tetroxide (Electron Microscopy Sciences) for $1 \mathrm{~h}$ at $4^{\circ} \mathrm{C}$ and dehydrated with graded ethanol $(25,50,70,90$ and 100\%) for 5 min each. After dehydration, samples were embedded in epoxy resin (Embed 812; Electron Microscopy Sciences) for $48 \mathrm{~h}$ at $60^{\circ} \mathrm{C}$, according to the manufacturer's instructions. Ultra-thin sections $(60 \mathrm{~nm})$ were prepared using an LKB-III ultramicrotome (Leica Microsystems $\mathrm{GmbH}$ ) and stained with $0.5 \%$ uranyl acetate (Electron Microscopy Sciences) for $20 \mathrm{~min}$ and $0.1 \%$ lead citrate (Electron Microscopy Sciences) for $7 \mathrm{~min}$ at room temperature. Images were captured at x10,000 magnification on a Hitachi H7650 electron microscope (Hitachi, Ltd.) installed at the Center for University-Wide Research Facilities at Jeonbuk National University (Republic of Korea).

RNA interference. Small interfering RNA (siRNA) targeting DR5 and scramble control siRNA were purchased from Ambion (Thermo Fisher Scientific, Inc.). The transfection reagent Lipofectamine ${ }^{\circledR} 2000$ was obtained from Invitrogen (Thermo Fisher Scientific, Inc.). A549 lung cancer cells $\left(1 \times 10^{5}\right.$ cells/well $)$ were transfected with 40 nM DR5 siRNA (siRNA ID 104279; Sequence 5'-UUUAGCCACCUUUAU CUCAUUGUCC-3'; Ambion; Thermo Fisher Scientific, Inc.) using Lipofectamine 2000, according to the manufacturer's protocol. The cells were incubated with siRNA for $6 \mathrm{~h}$ and the medium was then changed to RPMI-1640 with $10 \%$ FBS for $24 \mathrm{~h}$. Cells were then treated with sertraline, or sertraline in combination with TRAIL. At 24-h post transfection, knockdown efficiency was assessed by the cell viability assay and immunoblotting at the protein level.

Data analysis. Data are expressed as the mean \pm SD. The significance of the differences between treatments were analyzed using one-way ANOVA followed by Tukey's test.
Statistical analyses were performed using GraphPad Prism 5 software (GraphPad Software, Inc.). $\mathrm{P}<0.05$ was considered to indicate a statistically significant difference.

\section{Results}

Sertraline induces TRAIL-mediated apoptosis in lung cancer cell lines. Effects of sertraline on TRAIL-mediated apoptosis were evaluated following the treatment of lung adenocarcinoma cells. Human lung cancer cell lines (A549, HCC-15 and Calu-3) were preincubated with the indicated doses of sertraline for $18 \mathrm{~h}$ and then treated with TRAIL for $2 \mathrm{~h}$ and $30 \mathrm{~min}$. Cells were imaged and variations in morphology related to apoptosis, such as cell shrinkage, were investigated under a light microscope. Cells treated with sertraline or TRAIL alone had slight changes in viability and showed no obvious morphological changes compared with control cells (Fig. 1). Thus, indicating that A549, HCC-15 and Calu-3 cells were highly resistant to TRAIL-mediated apoptosis. However, treatment with different concentrations of sertraline along with TRAIL significantly increased the number of apoptotic cells (Fig. 1A, B, E, F, I and J). The result of the MTT assay showed that combination treatment with sertraline and TRAIL reduced cell viability, which indicated that the number of apoptotic cells increased, for all cell lines tested (Fig. 1C, G and K). Sertraline or TRAIL alone failed to cause any significant increase in levels of LDH. Whereas, sertraline in combination with TRAIL significantly increased the level of LDH in all cell lines, indicative of apoptosis induction in a sertraline dose-dependent manner (Fig. 1D, H and L). These results demonstrated that sertraline could sensitize TRAIL-resistant human lung adenocarcinoma A549, HCC-15 and Calu-3 cells to TRAIL-mediated apoptosis.

Sertraline triggers the upregulation of DR5 expression to induce TRAIL-mediated apoptosis. Next, the molecular function of sertraline in TRAIL-mediated apoptosis of A549 lung cancer cells was investigated (Fig. 2). A549 cells were treated with indicated doses of sertraline for $18 \mathrm{~h}$, and the harvested cell lysates were analyzed by western blotting to determine DR4 and DR5 expression. Sertraline upregulated DR5 expression in a dose-dependent manner in A549 cells; however, the expression of DR4 was unaltered (Fig. 2A). A549 cells were preincubated with the indicated doses of sertraline for $18 \mathrm{~h}$ and then exposed to TRAIL for $2 \mathrm{~h}$. Intracellular apoptosis-regulatory proteins, cleaved caspase- 8 and cleaved caspase-3, were activated in cells subjected to a combined treatment of sertraline and TRAIL compared with cells treated with sertraline alone (Fig. 2B). Furthermore, ICC results revealed the increased expression of DR5 in sertraline-treated cells compared with that in non-treated cells (Fig. 2C). These findings indicated that sertraline could induce TRAIL-mediated apoptosis in lung adenocarcinoma cells by upregulating DR5 expression.

Sertraline inhibits autophagic flux via the downregulation of $A M P K$ phosphorylation. To explore the outcomes of sertraline exposure on autophagic flux, LC3-II and p62 expression levels were assessed by western blotting (Fig. 3). The expression levels of LC3-II and p62 increased after sertraline treatment, 
A

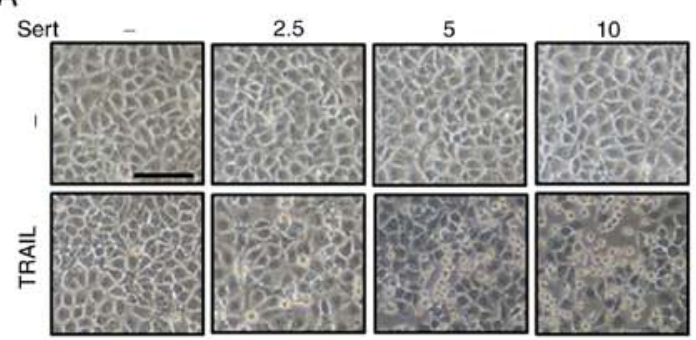

C

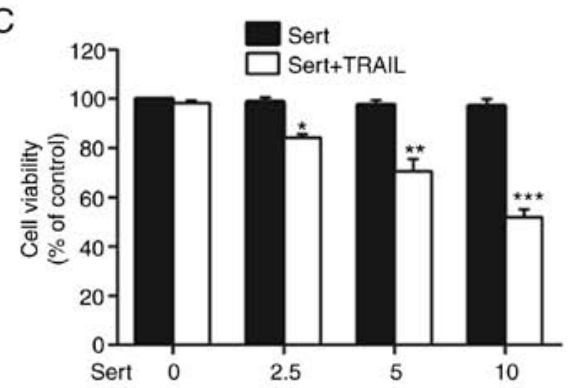

$E$

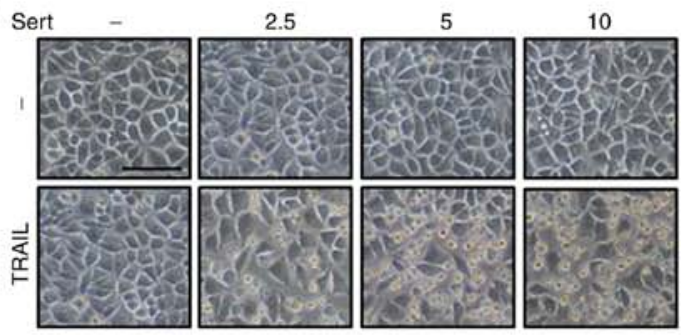

G

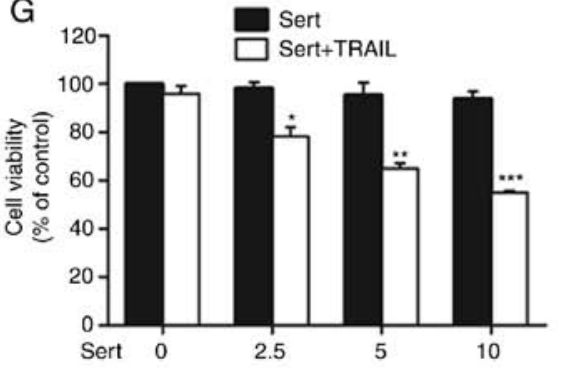

I Sert
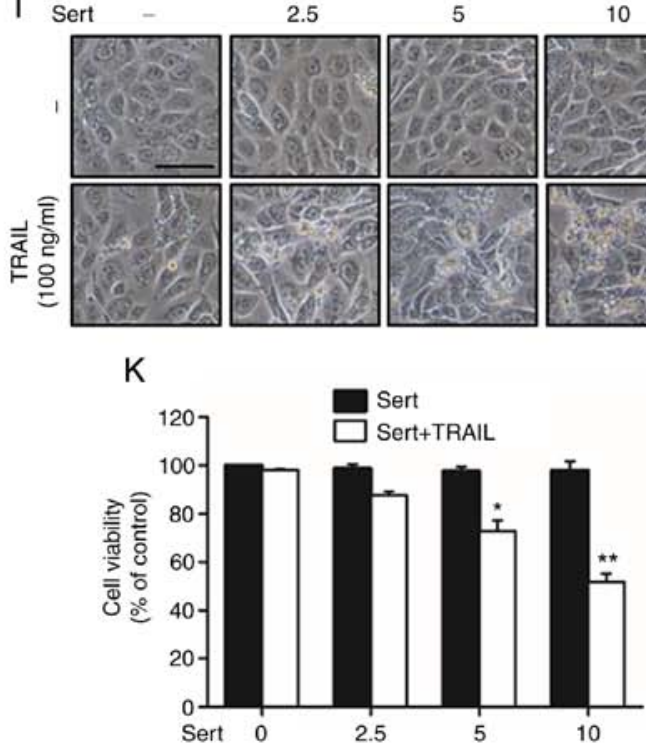

B

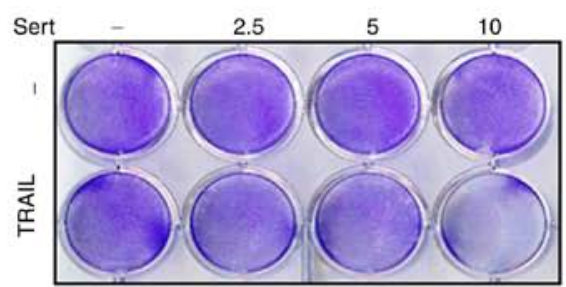

D

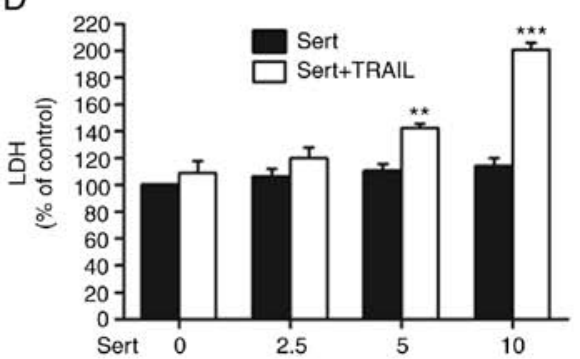

$F$
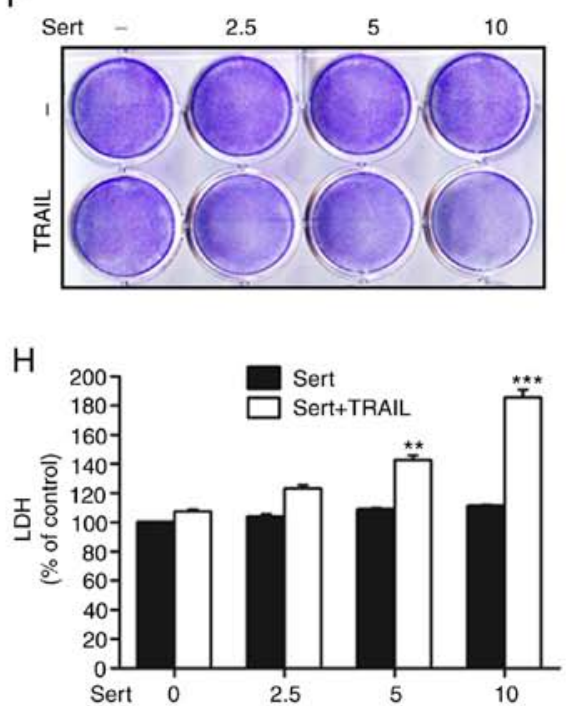

$J$

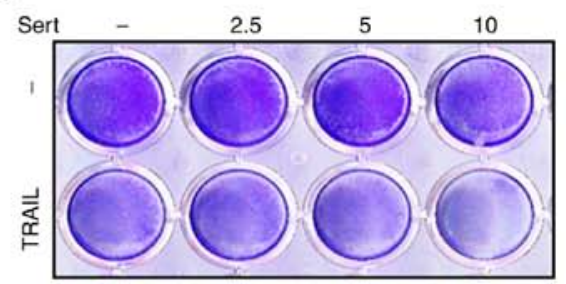

L

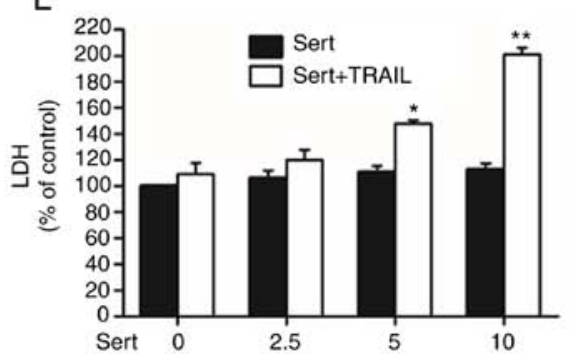

Figure 1. Sert induces TRAIL-mediated apoptosis in lung cancer cell lines. (A-D) A549, (E-H) HCC-15 and (I-L) Calu-3 cells were preincubated with the indicated concentrations of sert for $18 \mathrm{~h}$ and $100 \mathrm{ng} / \mathrm{ml}$ TRAIL for $2 \mathrm{~h}$ and $30 \mathrm{~min}$. (A, E and I) Cells were imaged and variations in morphology were examined under a light microscope (magnification, x100; scale bar, $50 \mu \mathrm{m}$ ). (B, F and J) Crystal violet staining was performed to determine cell viability. (C, G and K) MTT assays were conducted to reveal cell viability, which are expressed as bar graphs. (D, H and L) Secretion of LDH during co-treatment was assessed in the collected supernatants. ${ }^{*} \mathrm{P}<0.05,{ }^{* *} \mathrm{P}<0.01,{ }^{* * *} \mathrm{P}<0.001$ vs. untreated (control) group Sert, sertraline; TRAIL, tumor necrosis factor-related apoptosis-inducing ligand; LDH, lactate dehydrogenase. 
A

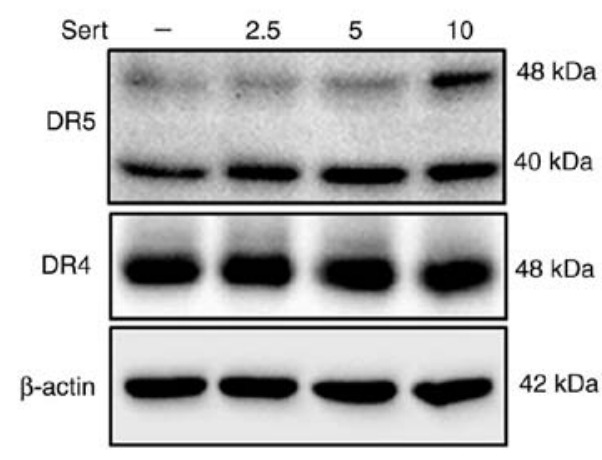

B

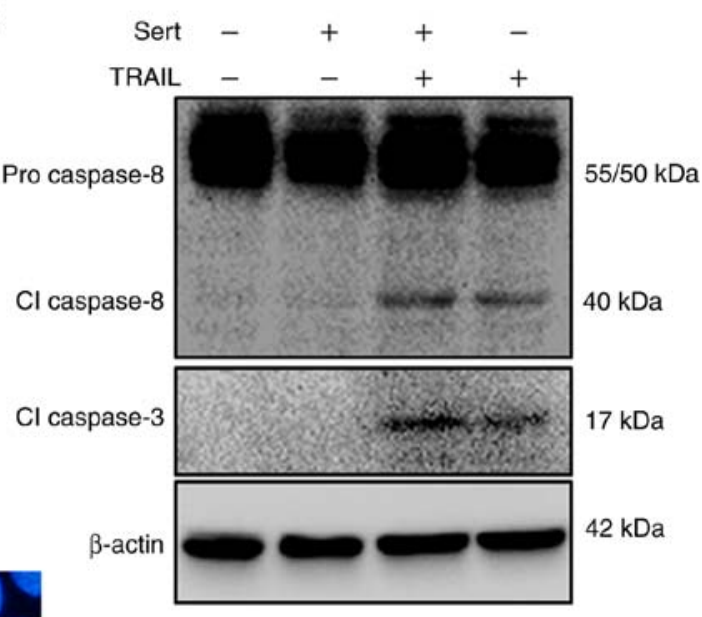

C Con
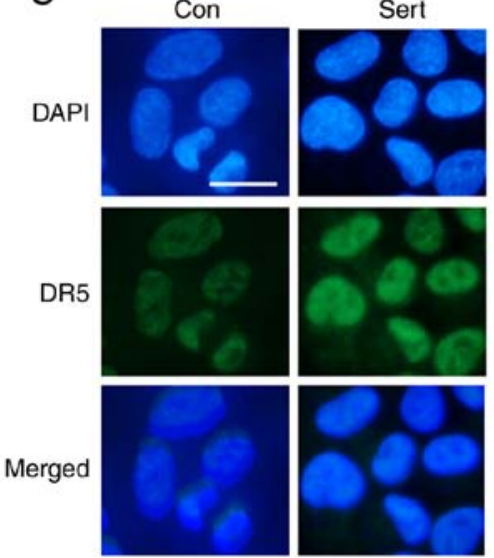

Figure 2. Sert upregulates the expression of DR5 to induce TRAIL-mediated apoptosis. A549 cells were incubated with the indicated doses of sert for $18 \mathrm{~h}$. (A) Harvested cell lysates were collected and subjected to western blotting to evaluate DR5 and DR4 expression. (B) Cells were treated with sert (10 $\mu \mathrm{M}$ ) for $18 \mathrm{~h}$ and then exposed to TRAIL protein $(100 \mathrm{ng} / \mathrm{ml})$ for $2 \mathrm{~h}$. Intracellular apoptosis regulatory proteins, cleaved caspase- 8 and cleaved caspase-3, were detected by immunoblot analysis. (C) Immunocytochemistry also showed that DR5 expression was upregulated in sert-treated cells (scale bar, $50 \mu \mathrm{m}$ ). Sert, sertraline; TRAIL, tumor necrosis factor-related apoptosis-inducing ligand; DR5, death receptor 5; DR4, death receptor 4.

indicating the inhibition of autophagic flux (Fig. 3A). Treatment with sertraline alone or in combination with TRAIL upregulated LC3-II and p62 expression compared with TRAIL treatment alone (Fig. 3B). ICC results also showed that sertraline increased the expression of p62 (Fig. 3C). The AMPK pathway is involved in stabilizing cellular energy through the control of autophagic flux via downregulation of mTOR expression (29). Sertraline inhibited phosphorylation of AMPK, resulting in the inhibition of autophagic flux (Fig. 3D). TEM revealed the inhibition of autophagic flux, as confirmed by the accumulation of autophagic vacuoles containing intracellular material in the treatment group (Fig. 3E). These findings indicated that the inhibition of AMPK phosphorylation by sertraline may result in the suppression of autophagic flux in lung cancer cells.

Sertraline induces TRAIL-mediated apoptosis of cancer cells by inhibiting autophagic flux. The well-known autophagy inhibitors chloroquine and 3-MA were used to examine the effects of sertraline-induced TRAIL-mediated apoptosis in A549 cells (Fig. 4). A549 cells were incubated with chloroquine, 3-MA and sertraline at the indicated concentrations for $18 \mathrm{~h}$. Then, cells were exposed to TRAIL for an additional $2 \mathrm{~h}$ and $30 \mathrm{~min}$. Cells were photographed to investigate any morphological changes under light microscope. Cell viability was analyzed by crystal violet staining and an MTT assay. The number of dead A549 cells increased slightly after treatment with either TRAIL or sertraline alone. However, the combination of TRAIL and chloroquine or 3-MA notably increased cell death. Based on cellular morphology, it was observed that TRAIL with sertraline, chloroquine or 3-MA enhanced cell death compared with sertraline or TRAIL alone (Fig. 4A and B). The MTT assay showed that both autophagy inhibitors, chloroquine and 3-MA, in combination with TRAIL significantly decreased the viability of A549 cells compared with control cells (Fig. 4C). Additionally, the combination of TRAIL and chloroquine or 3-MA also enhanced LDH release compared with control cells (Fig. 4D). These results indicated that sertraline enhanced the TRAIL-mediated apoptosis of lung cancer cells by inhibiting autophagic flux.

Autophagic flux inhibition leads to the upregulation of DR5 expression and enhances sertraline-induced TRAIL-mediated apoptosis. To further explore the mechanism underlying sertraline-induced TRAIL-mediated apoptosis, autophagic flux was inhibited using autophagy inhibitors, chloroquine and 3-MA. Inhibition of autophagic flux with chloroquine and 3-MA resulted in the upregulation of DR5 expression, thereby increasing apoptosis (Fig. 5B). Cells were treated with the indicated concentration of sertraline and two autophagy inhibitors [chloroquine $(10 \mu \mathrm{M})$ and 3-MA $(5 \mathrm{mM})$ ] for $18 \mathrm{~h}$. Cell lysates were collected for western blotting and it was found that sertraline and chloroquine treatment notably increased the 
A

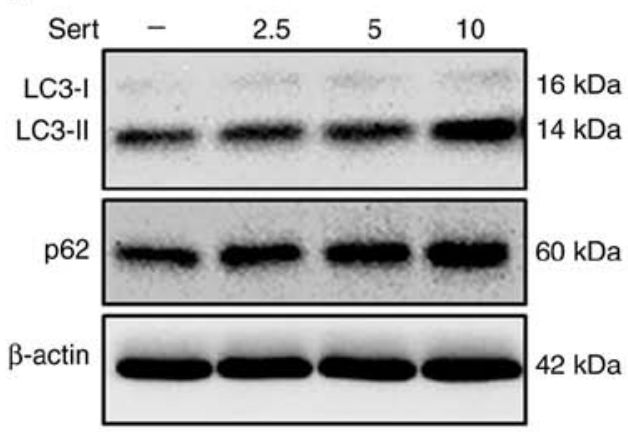

C
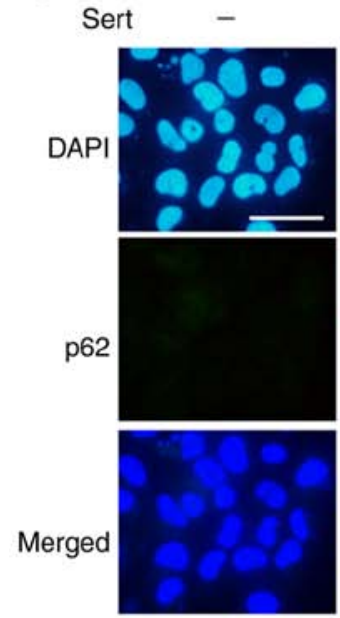

5

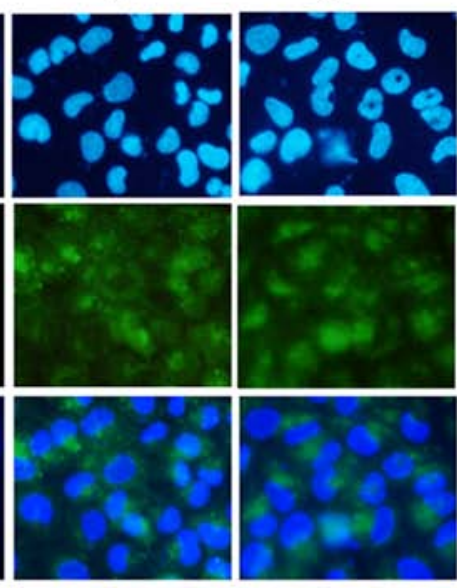

E
B

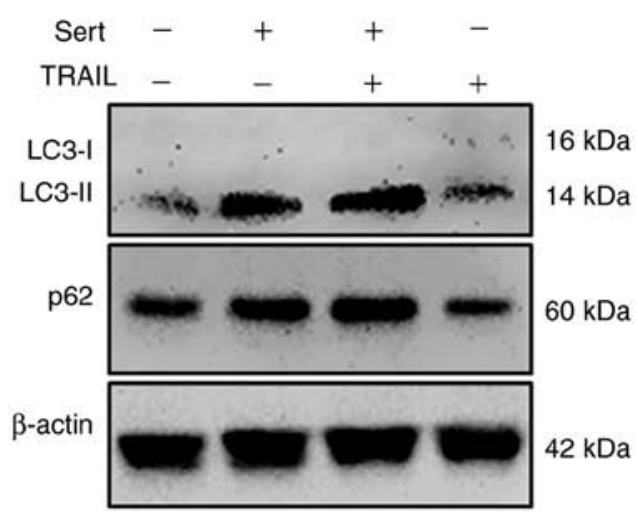

D

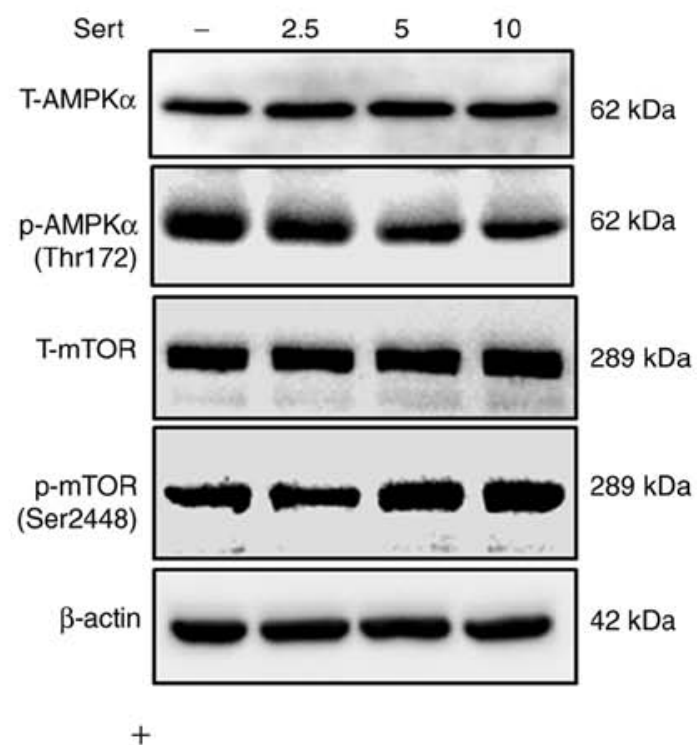

Sert

$-$
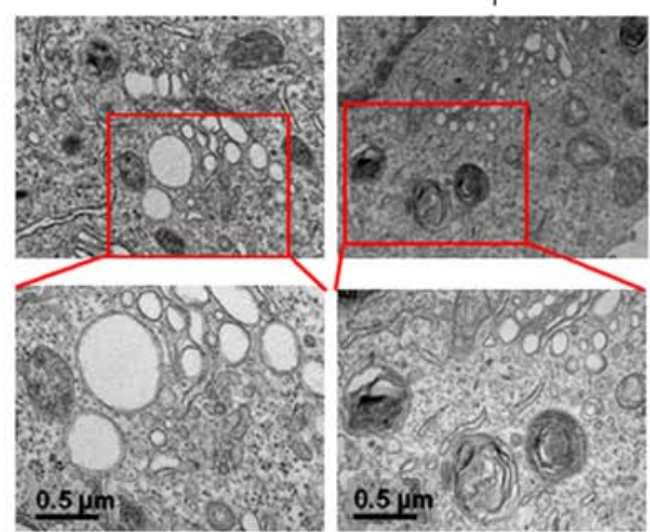

Figure 3. Sert inhibits autophagic flux via the downregulation of AMPK phosphorylation. A549 cells were incubated with the indicated doses of sert for $18 \mathrm{~h}$ (A and D) LC3 conversion and p62, p-AMPK $\alpha$ and p-mTOR levels were evaluated by western blot analysis. (B) Sert (10 $\mu$ M)-treated cells were incubated for $18 \mathrm{~h}$ and exposed to TRAIL protein $(100 \mathrm{ng} / \mathrm{ml})$ for $2 \mathrm{~h}$. The expression levels of p62, LC3-I and -II were analyzed by western blotting. (C) The increase in the expression of p62 mediated by sert was analyzed by immunocytochemistry (scale bar, $50 \mu \mathrm{m}$ ). (E) Transmission electron microscopy results showed the accumulation of autophagosomes (Scale bar, $0.5 \mu \mathrm{m}$ ). Sert, sertraline; TRAIL, tumor necrosis factor-related apoptosis-inducing ligand; AMPK, AMP-activated protein kinase; LC3, microtubule-associated protein 1 light chain 3; T-, total protein; p-, phosphorylated; mTOR, mammalian target of rapamycin.

expression levels of p62 and LC3-II; 3-MA could also slightly increase p62 and LC3-II expression (Fig. 5A). Moreover, DR5 expression in the chloroquine or 3-MA groups was similar to that observed with sertraline treatment alone (Fig. 5B). The expression of key apoptosis indicators, cleaved caspase- 8 and cleaved caspase- 3 , were also evaluated in the lysates of the cells treated with chloroquine, 3-MA and sertraline with the indicated doses for $18 \mathrm{~h}$, and TRAIL for $2 \mathrm{~h}$. Autophagy inhibitors chloroquine and 3-MA in the presence of TRAIL could trigger the expression of cleaved caspase- 8 and cleaved caspase-3 (Fig. 5C). Taken together, these findings suggested that the inhibition of autophagy may result in the upregulation of DR5 expression and sertraline-induced TRAIL-mediated apoptosis. 
A

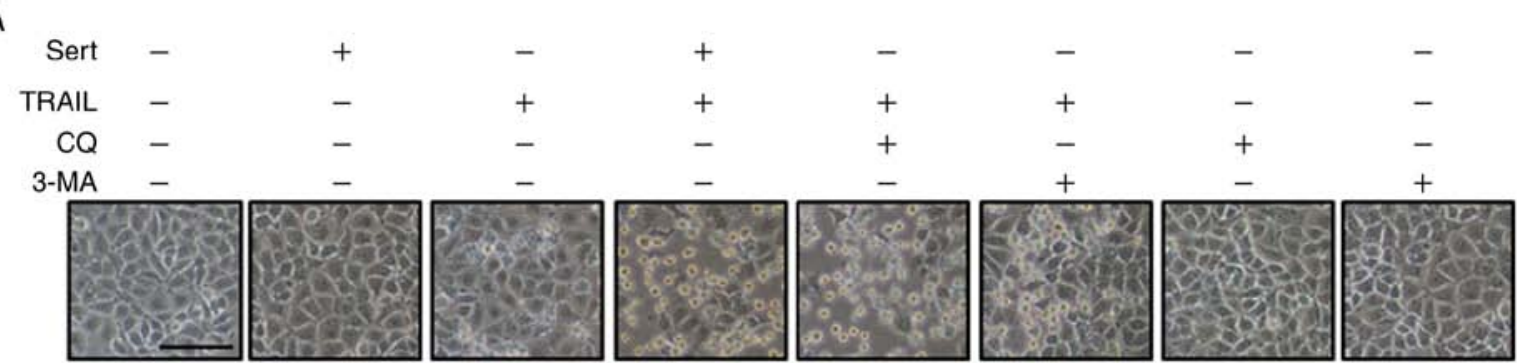

B

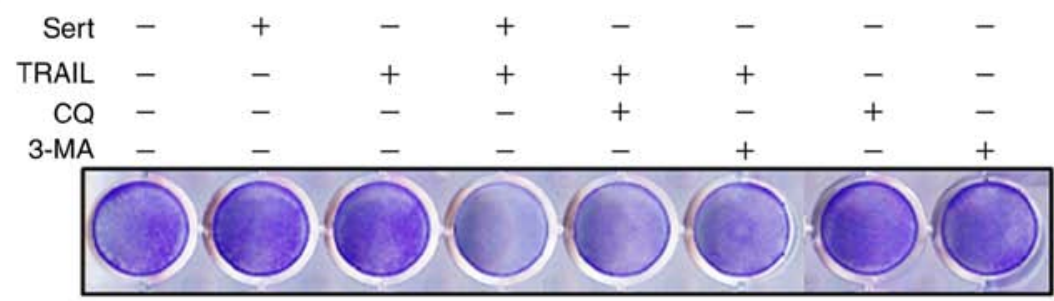

C

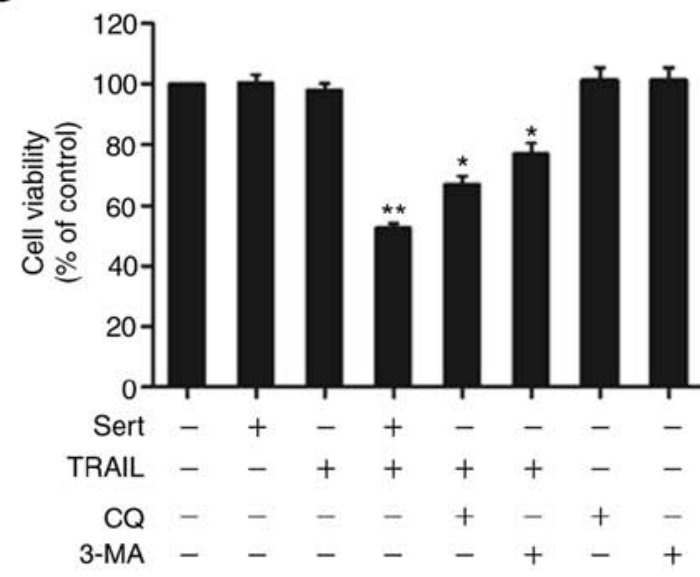

D

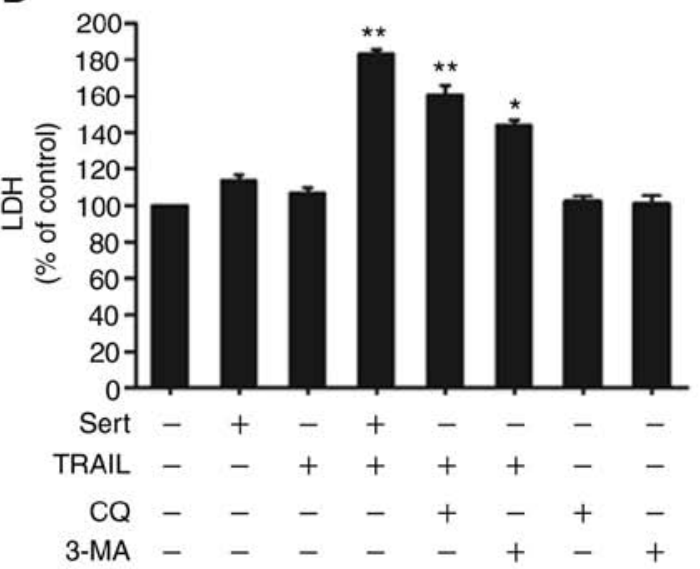

Figure 4. Sert enhances TRAIL-mediated apoptosis by inhibiting autophagic flux. Cells were preincubated with or without CQ (10 $\mu \mathrm{M}), 3-\mathrm{MA}$ (5 mM) and sert $(10 \mu \mathrm{M})$ for $18 \mathrm{~h}$. Cells were then exposed to TRAIL $(100 \mathrm{ng} / \mathrm{ml})$ for $2 \mathrm{~h}$ and $30 \mathrm{~min}$. (A) Cell morphology was captured under a light microscope (magnification, x100; scale bar, $50 \mu \mathrm{m}$ ). (B) Crystal violet staining was performed to determine cell viability. (C) An MTT assay was performed and the cell viability result is presented as a bar graph. (D) LDH levels in the collected supernatants were analyzed. ${ }^{*} \mathrm{P}<0.01$ and ${ }^{* * *} \mathrm{P}<0.001$ vs. untreated (control) group. Sert, sertraline; TRAIL, tumor necrosis factor-related apoptosis-inducing ligand; CQ, chloroquine; LDH, lactate dehydrogenase; 3-MA, 3-methyladenine.

Silencing of DR5 expression alters sertraline-induced TRAIL-mediated apoptosis. Silencing DR5 expression using DR5 siRNA significantly altered the effect on cell viability (Fig. 6). This experiment showed that DR5 plays a key role in sertraline-induced TRAIL-mediated apoptosis of cancer cells.
After $24 \mathrm{~h}$ of transfection with DR5 siRNA or scramble control siRNA, cells were treated with sertraline for $18 \mathrm{~h}$ and then with TRAIL $(100 \mathrm{ng} / \mathrm{ml})$ for $2 \mathrm{~h}$ and $30 \mathrm{~min}$. Cells were then subjected to viability and western blot analyses. As a result, it was found that DR5 siRNA-transfected cells blocked cell 
A

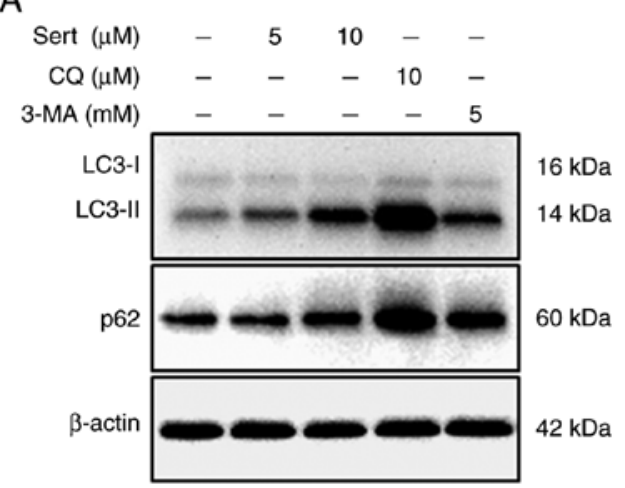

B

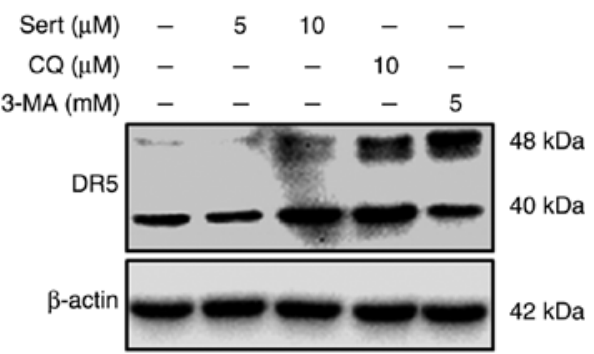

C

$\begin{array}{rcccccc}\text { Sert } & - & + & - & - & - & - \\ \text { TRAIL } & + & + & + & + & - & - \\ \text { CQ } & - & - & + & - & + & - \\ \text { 3-MA } & - & - & - & + & - & +\end{array}$

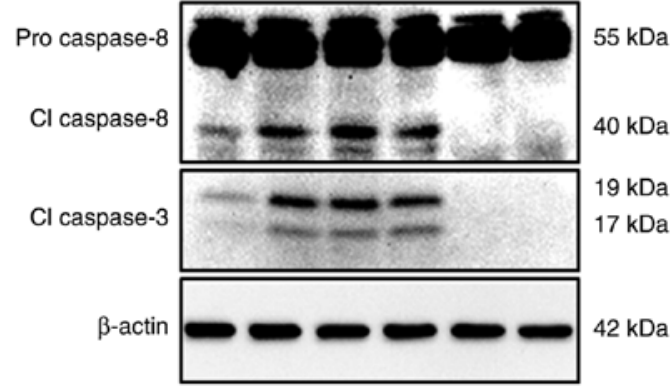

Figure 5. Autophagic flux inhibition leads to the upregulation of DR5 expression and enhances sert-induced TRAIL-mediated apoptosis. Cells were incubated with or without sertraline $(10 \mu \mathrm{M}), \mathrm{CQ}(10 \mu \mathrm{M})$ or 3-MA $(5 \mathrm{mM})$ for $18 \mathrm{~h}$. (A) p62, LC3-I and -II expression was evaluated by western blotting. (B) DR5 expression was assessed by western blotting. (C) Cells were treated with or without sert $10(\mu \mathrm{M}), \mathrm{CQ}(10 \mu \mathrm{M})$ or 3-MA $(5 \mathrm{mM})$ for $18 \mathrm{~h}$ and then exposed to TRAIL $(100 \mathrm{ng} / \mathrm{ml})$ for $2 \mathrm{~h}$. Western blotting was performed to evaluate the expression of cleaved caspase- 8 and cleaved caspase-3. Sert, sertraline; TRAIL, tumor necrosis factor-related apoptosis-inducing ligand; CQ, chloroquine; 3-MA, 3-methyladenine; LC3-I, microtubule-associated protein 1 light chain 3; DR5, death receptor 5.

A

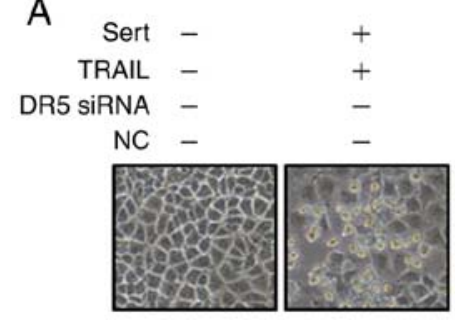

C

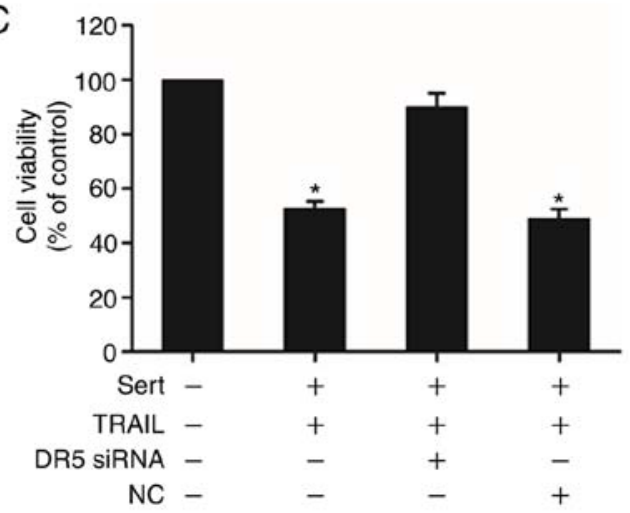

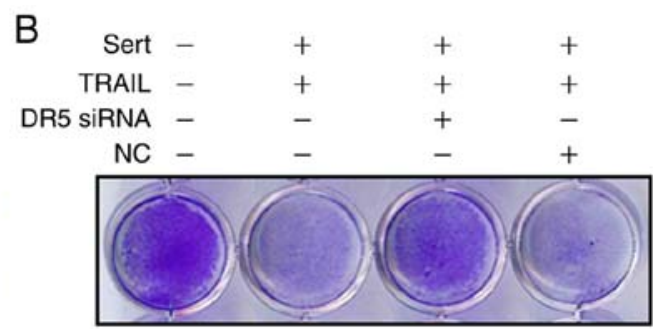

D

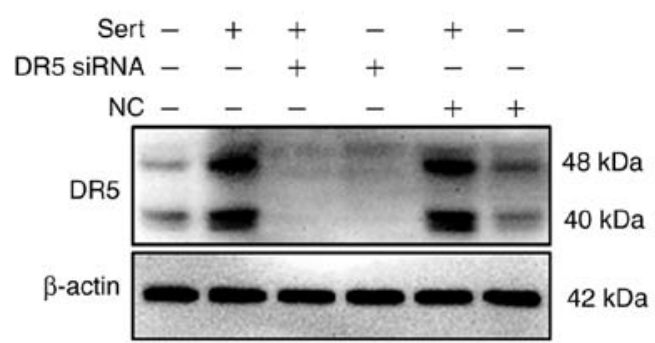

Figure 6. Blocking DR5 expression alters the effect of sert on TRAIL-mediated apoptosis. Cells were transfected with DR5 siRNA or scramble siRNA $(40 \mathrm{nM})$ for $24 \mathrm{~h}$ and then treated with sert $(10 \mu \mathrm{M})$ for $18 \mathrm{~h}$ before exposure to TRAIL protein $(100 \mathrm{ng} / \mathrm{ml})$ for $2 \mathrm{~h}$ and 30 min. (A) Cells were photographed and morphological variations were examined under light microscope (magnification, x100; scale bar, $50 \mu \mathrm{m}$ ). (B) Crystal violet staining was used to determine cell viability; (C) MTT assay was performed and the cell viability result is presented as a bar graph. (D) Cell lysates were collected and used for western blotting to determine the expression of DR5. "P<0.001 vs. untreated (control) group. Sert, sertraline; TRAIL, tumor necrosis factor-related apoptosis-inducing ligand; DR5, death receptor 5; siRNA, small interfering RNA; NC, negative control. 
death despite co-treatment with sertraline and TRAIL. The viability of cells treated with scramble siRNA was similar to that of the cells exposed to sertraline and TRAIL co-treatment (Fig. 6A-C). Western blot analysis showed that DR5 expression was inhibited in DR5 siRNA-transfected cells compared with that in non-transfected cells. These experimental findings indicated that sertraline-mediated upregulation of DR5 plays an important role in weakening TRAIL resistance. Overall, these findings demonstrated that the induction of TRAIL-mediated apoptosis with sertraline via AMPK-mediated autophagic flux inhibition is a possible therapeutic strategy to target the TRAIL-DR5 apoptotic pathway.

\section{Discussion}

In the present study, the effect of sertraline alone and in combination with TRAIL on A549 lung cancer cells was investigated. The findings highlighted that sertraline increased the expression of DR5 via the inhibition of autophagic flux, thereby resulting in an increase in the TRAIL-induced apoptosis of A549 cells.

The treatment of patients with lung cancer using antidepressants was found to increase their survival rate, but the underlying mechanism of action is not completely understood (2). Antidepressants are commonly used in patients with cancer to release emotional stress, such as depression and dysthymia. Antidepressants, such as fluoxetine and sertraline, can help to prevent stress-induced tumor progression (30). Chronic stress decreases the antitumor immune response, thereby increasing tumor growth (31). A number of studies in animal models have shown that behavioral stress induces the rapid progression of ovarian cancer (32), pancreatic cancer (33), prostate cancer (34), breast carcinomas (35) and malignant melanomas (36). It has already been demonstrated that SSRI treatment may reduce the risk of lung cancer (37). The antitumor effects of several SSR Is in various types of cancer cells have been described. Paroxetine, an SSRI, was reported to induce the apoptotic death of human osteosarcoma cells via the activation of p38 MAPK and caspase-3 pathways (38). Fluoxetine, another SSRI, could prevent the propagation of prostate cancer cells both in vitro and in vivo, and induce apoptosis of glioma cells $(39,40)$. In addition, SSRIs sertraline and paroxetine were demonstrated to increase the activity of caspase-3, decrease the expression of Bcl-2, and significantly reduce the viability of malignant $\mathrm{T}$ cells (41).

TRAIL is considered as one of the most favorable anticancer agents, given its specific action involving the induction of apoptosis in cells and stimulation of cancer cell death without affecting the functions of normal cells $(42,43)$. Previous experiments have reported that the repetitive application of TRAIL can markedly prevent tumor growth without damaging normal cells $(44,45)$. However, several cancer cells, including lung cancer cells, have developed resistance to the apoptotic effects of TRAIL (46). TRAIL resistance can be overcome through the use of combination therapy with efficient TRAIL-sensitizing pharmacological agents (47).

The present study demonstrated that small doses of sertraline in combination with TRAIL could notably increase the apoptosis of cancer cells. These experiments showed that lung cancer cells (A549, HCC-15 and Calu-3) are TRAIL resistant. Furthermore, it was confirmed that sertraline in combination with TRAIL upregulated the expression of DR5, thereby promoting cancer cell death. Although TRAIL can bind to the decoy receptors DcR1 and DcR2 and soluble osteoprotegerin, only DR4 and DR5 can trigger apoptotic signals through their intracellular death domains (43). These results clarified that sertraline could attenuate TRAIL resistance and activate the apoptotic caspase cascade (Figs. 1 and 2).

Autophagy is a self-regulated mechanism in cells and is related to cell death and survival. It plays a vital role in cell survival by eliminating damaged cellular components and facilitating the degradation of misfolded or aggregated proteins (48). Autophagy supports the recycling of essential cell components to fuel bioenergetics machinery. A number of studies have suggested that the prevention of lysosomal degradation in starved cells may enhance the rate of apoptosis via the activation of death receptors $(20,49)$. AMPK plays an important role in cellular energy homeostasis by inducing autophagy via mTOR inhibition. Downregulation of AMPK phosphorylation induces apoptotic cell death via autophagic flux inhibition (50). LC3-II is a well-known marker indicating the formation of a complete autophagosome, while p62 is involved in the lysosome- and proteasome-dependent degradation of proteins. Inhibition of autophagy results in the accumulation of cellular p62 (51). The findings of the present study suggested that sertraline increases the number of autophagosomes, as evident from the enlarged volume of LC3-II, and triggers the degradation of lysosomes, consistent with the accumulation of p62. The consequences of these two events is the inhibition of autophagic flux (Fig. 3). This study further revealed that combined treatment with TRAIL and sertraline, TRAIL and chloroquine, or TRAIL and 3-MA could increase cell viability compared with a single treatment regimen. 3-MA inhibits autophagy by preventing autophagosome formation via the suppression of PI3K, while chloroquine inhibits the autophagic flux by blocking the acidification of lysosomes $(52,21)$. The present study also demonstrated that autophagic flux inhibition by sertraline facilitates TRAIL-induced apoptosis, as confirmed by the use of autophagy inhibitors chloroquine and 3-MA (Fig. 4) $(53,54)$. The inhibition of autophagic flux using sertraline and autophagy inhibitors, 3-MA and chloroquine, mediated the upregulation of DR5 expression and increased TRAIL-mediated apoptotic cell death of lung cancer cells (Fig. 5). The silencing of DR5 expression using DR5 siRNA reduced TRAIL-mediated apoptosis of cancer cells (Fig. 6).

Taken together, the present results suggested that sertraline may serve as a prospective candidate to prevent TRAIL resistance, and in combination with TRAIL may be an active treatment regimen to treat lung cancer. The present findings are based on cell culture experiments. Thus, further investigations are required with an animal model. However, this study lays the foundation of future studies to determine patient-specific treatment strategies in those affected by both depression and cancer.

\section{Acknowledgements}

Not applicable. 


\section{Funding}

This study was supported by a grant from National Research Foundation of the Korea (NRF) funded by the Ministry of Education (grant no. 2019R1A6A1A03033084).

\section{Availability of data and materials}

All datasets generated or analyzed during the present study are available from the corresponding author upon reasonable request.

\section{Authors' contributions}

$\mathrm{KZ}$ and SP designed and performed the study, and KZ, JS and SP analyzed data and wrote the manuscript. All authors have read and approved the final manuscript.

\section{Ethics approval and consent to participate}

Ethical approval for the project was granted by the Institutional Review Board of The Jeonbuk National University.

\section{Patient consent for publication}

Not applicable.

\section{Competing interests}

The authors declare that they have no competing interests.

\section{References}

1. Bray F, Ferlay J, Soerjomataram I, Siegel RL, Torre LA and Jemal A: Global cancer statistics 2018: GLOBOCAN estimates of incidence and mortality worldwide for 36 cancers in 185 countries. CA Cancer J Clin 68: 394-424, 2018.

2. Zingone A, Brown D, Bowman ED, Vidal O, Sage J, Neal J and Ryan BM: Relationship between anti-depressant use and lung cancer survival. Cancer Treat Res Commun 10: 33-39, 2017.

3. Schelhaas S, Held A, Wachsmuth L, Hermann S, Honess DJ, Heinzmann K, Smith DM, Griffiths JR, Faber C and Jacobs AH: Gemcitabine mechanism of action confounds early assessment of treatment response by 3'-Deoxy-3'-[18F]Fluorothymidine in preclinical models of lung cancer. Cancer Res 76: 7096-7105, 2016.

4. Garcia G and Odaimi M: Systemic combination chemotherapy in elderly pancreatic cancer: A review. J Gastrointest Cancer 48: 121-128, 2017.

5. Sun W, Sanderson PE and Zheng W: Drug combination therapy increases successful drug repositioning. Drug Discov Today 21: $1189-1195,2016$

6. Uchibori K, Inase N, Araki M, Kamada M, Sato S, Okuno Y, Fujita $\mathrm{N}$ and Katayama R: Brigatinib combined with anti-EGFR antibody overcomes osimertinib resistance in EGFR-mutated non-small-cell lung cancer. Nat Commun 8: 14768, 2017.

7. Aggarwal BB: Signalling pathways of the TNF superfamily: A double-edged sword. Nat Rev Immunol 3: 745-756, 2003.

8. Mellier G, Huang S, Shenoy K and Pervaiz S: TRAILing death in cancer. Mol Aspects Med 31: 93-112, 2010.

9. Nazim UM, Rasheduzzaman M, Lee YJ, Seol DW and Park SY: Enhancement of TRAIL-induced apoptosis by 5-fluorouracil requires activating Bax and p53 pathways in TRAIL-resistant lung cancers. Oncotarget 8: 18095-18105, 2017.

10. O'Leary L, van der Sloot AM, Reis CR, Deegan S, Ryan AE, Dhami SPS, Murillo LS, Cool RH, Sampaio PC, Thompson K, et al: Decoy receptors block TRAIL sensitivity at a supracellular level: The role of stromal cells in controlling tumour TRAIL sensitivity. Oncogene 35: 1261-1270, 2016.

11. Wang S and El-Deiry WS: TRAIL and apoptosis induction by TNF-family death receptors. Oncogene 22: 8628-8633, 2003.
12. Wang S: The promise of cancer therapeutics targeting the TNF-related apoptosis-inducing ligand and TRAIL receptor pathway. Oncogene 27: 6207-6215, 2008.

13. Wu GS: TRAIL as a target in anti-cancer therapy. Cancer Lett 285: 1-5, 2009.

14. Jin CY, Park C, Hwang HJ, Kim GY, Choi BT, Kim WJ and Choi YH: Naringenin up-regulates the expression of death receptor 5 and enhances TRAIL-induced apoptosis in human lung cancer A549 cells. Mol Nutr Food Res 55: 300-309, 2011.

15. Dai X, Zhang J, Arfuso F, Chinnathambi A, Zayed ME, Alharbi SA, Kumar AP, Ahn KS and Sethi G: Targeting TNF-related apoptosis-inducing ligand (TRAIL) receptor by natural products as a potential therapeutic approach for cancer therapy. Exp Biol Med (Maywood) 240: 760-773, 2015.

16. Ding J, Polier G, Köhler R, Giaisi M, Krammer PH and Li-Weber M: Wogonin and related natural flavones overcome tumor necrosis factor-related apoptosis-inducing ligand (TRAIL) protein resistance of tumors by down-regulation of c-FLIP protein and up-regulation of TRAIL receptor 2 expression. J Biol Chem 287: 641-649, 2012.

17. Mizushima N, Yoshimori T and Levine B: Methods in mammalian autophagy research. Cell 140: 313-326, 2010.

18. Tanida I, Minematsu-Ikeguchi N, Ueno T and Kominami E: Lysosomal turnover, but not a cellular level, of endogenous LC3 is a marker for autophagy. Autophagy 1: 84-91, 2005.

19. Gómez-Sánchez R, Yakhine-Diop SMS, Rodríguez-Arribas M, Pedro JMB, Martínez-Chacón G, Uribe-Carretero E, de Castro DCJ, Pizarro-Estrella E, Fuentes JM and González-Polo RA: mRNA and protein dataset of autophagy markers (LC3 and p62) in several cell lines. Data Brief 7: 641-647, 2016.

20. Boya P, González-Polo R, Casares N, Perfettini J, Dessen P, Larochette N, Métivier D, Meley D, Souquere S, Yoshimori T, et al: Inhibition of macroautophagy triggers apoptosis. Mol Cell Biol 25: 1025-1040, 2005.

21. Mauthe M, Orhon I, Rocchi C, Zhou X, Luhr M, Hijlkema K, Coppes RP, Engedal N, Mari M and Reggiori F: Chloroquine inhibits autophagic flux by decreasing autophagosome-lysosome fusion. Autophagy 14: 1435-1455, 2018.

22. Heckmann BL, Yang X, Zhang X and Liu J: The autophagic inhibitor 3-methyladenine potently stimulates PKA-dependent lipolysis in adipocytes. Br J Pharmacol 168: 163-171, 2013.

23. Kahn BB, Alquier T, Carling D and Hardie DG: AMP-activated protein kinase: Ancient energy gauge provides clues to modern understanding of metabolism. Cell Metab 1: 15-25, 2005.

24. Zhou C, Gu J, Zhang G, Dong D, Yang Q, Chen M and Xu D: AMPK-autophagy inhibition sensitizes icaritin-induced anti-colorectal cancer cell activity. Oncotarget 8: 14736-14747, 2017.

25. Cho SW, Na W, Choi M, Kang SJ, Lee S and Choi CY: Autophagy inhibits cell death induced by the anti-cancer drug morusin. Am J Cancer Res 7: 518-530, 2017.

26. Laoutidis ZG and Mathiak K: Antidepressants in the treatment of depression/depressive symptoms in cancer patients: A systematic review and meta-analysis. BMC Psychiatry 13: 140, 2013.

27. Serafin MB, Bottega A, da Rosa TF, Machado CS, Foletto VS, Coelho SS, da Mota AD and Hörner R: Drug repositioning in oncology. Am J Ther 2019.

28. Xia D, Zhang Y, Xu G, Yan W, Pan X and Tong J: Sertraline exerts its antitumor functions through both apoptosis and autophagy pathways in acute myeloid leukemia cells. Leuk Lymphoma 58: 1-10, 2017.

29. Alers S, Löffler AS, Wesselborg $S$ and Stork B: Role of AMPK-mTOR-Ulk1/2 in the regulation of autophagy: Cross talk, shortcuts, and feedbacks. Mol Cell Biol 32: 2-11, 2012.

30. Di Rosso ME, Sterle HA, Cremaschi GA and Genaro AM: Beneficial effect of fluoxetine and sertraline on chronic stress-induced tumor growth and cell dissemination in a mouse model of lymphoma: Crucial role of antitumor immunity. Front Immunol 9: 1341, 2018.

31. Dhabhar FS, Saul AN, Holmes TH, Daugherty C, Neri E, Tillie JM, Kusewitt D and Oberyszyn TM: High-anxious individuals show increased chronic stress burden, decreased protective immunity, and increased cancer progression in a mouse model of squamous cell carcinoma. PLoS One 7: e33069, 2012.

32. Thaker PH, Han LY, Kamat AA, Arevalo JM, Takahashi R, Lu C, Jennings NB, Armaiz-Pena G, Bankson JA, Ravoori M, et al: Chronic stress promotes tumor growth and angiogenesis in a mouse model of ovarian carcinoma. Nat Med 12: 939-944, 2006. 
33. Kim-Fuchs C, Le CP, Pimentel MA, Shackleford D, Ferrari D, Angst E, Hollande F and Sloan EK: Chronic stress accelerates pancreatic cancer growth and invasion: A critical role for beta-adrenergic signaling in the pancreatic microenvironment. Brain Behav Immun 40: 40-47, 2014.

34. Hassan S, Karpova Y, Baiz D, Yancey D, Pullikuth A, FloresA Register T, Cline JM, D'Agostino Jr, Danial N, et al: Behavioral stress accelerates prostate cancer development in mice. J Clin Invest 123: 874-886, 2013.

35. Sloan EK, Priceman SJ, Cox BF, Yu S, Pimentel MA, Tangkanangnukul V, Arevalo JMG,Morizono K, Karanikolas BDW, Wu L, et al: The sympathetic nervous system induces a metastatic switch in primary breast cancer. Cancer Res 70: 7042-7052, 2010.

36. Hasegawa $\mathrm{H}$ and Saiki I: Psychosocial stress augments tumor development through beta-adrenergic activation in mice. Jpn J Cancer Res 93: 729-735, 2002.

37. Toh S, Rodríguez LAG and Hernández-Díaz S: Use of antidepressants and risk of lung cancer. Cancer Causes Control 18 1055-1064, 2007.

38. Chou CT, He S and Jan CR: Paroxetine-induced apoptosis in human osteosarcoma cells: Activation of p38 MAP kinase and caspase-3 pathways without involvement of $[\mathrm{Ca} 2+]$ i elevation Toxicol Appl Pharmacol 218: 265-273, 2007.

39. Abdul M, Logothetis CJ and Hoosein NM: Growth-inhibitory effects of serotonin uptake inhibitors on human prostate carcinoma cell lines. J Urol 154: 247-250, 1995.

40. Spanová A, Kovárů H, Lisá V, Lukásová E and Rittich B Estimation of apoptosis in C6 glioma cells treated with antidepressants. Physiol Res 46: 161-164, 1997.

41. Amit BH, Gil-Ad I, Taler M, Bar M, Zolokov A and Weizman A: Proapoptotic and chemosensitizing effects of selective serotonin reuptake inhibitors on $\mathrm{T}$ cell lymphoma/leukemia (Jurkat) in vitro. Eur Neuropsychopharmacol 19: 726-734, 2009.

42. LeBlanc H, Lawrence D, Varfolomeev E, Totpal K, Morlan J, Schow P, Fong S, Schwall R, Sinicropi D and Ashkenazi A: Tumor-cell resistance to death receptor-induced apoptosis through mutational inactivation of the proapoptotic $\mathrm{Bcl}-2$ homolog Bax. Nat Med 8: 274-281, 2002.

43. Srivastava RK: TRAIL/Apo-2L: Mechanisms and clinical applications in cancer. Neoplasia 3: 535-546, 2001.

44. Bellail AC, Qi L, Mulligan P, Chhabra V and Hao C: TRAIL agonists on clinical trials for cancer therapy: The promises and the challenges. Rev Recent Clin Trials 4: 34-41, 2009.
45. Walczak H, Miller RE, Ariail K, Gliniak B, Griffith TS, Kubin M, Chin W, Jones J, Woodward A, Le T, et al: Tumoricidal activity of tumor necrosis factor-related apoptosis-inducing ligand in vivo. Nat Med 5: 157-163, 1999.

46. Klionsky DJ: Autophagy: From phenomenology to molecular understanding in less than a decade. Nat Rev Mol Cell Biol 8: 931-937, 2007.

47. Shimizu S, Kanaseki T, Mizushima N, Mizuta $T$, Arakawa-Kobayashi S, Thompson CB and Tsujimoto Y: Role of Bcl-2 family proteins in a non-apoptotic programmed cell death dependent on autophagy genes. Nat Cell Biol 6: 1221-1228, 2004.

48. Glick D, Barth S and Macleod KF: Autophagy: Cellular and molecular mechanisms. J Pathol 221: 3-12, 2010.

49. Park EJ, Min K, Choi KS, Kubatka P, Kruzliak P, Kim DE and Kwon TK: Chloroquine enhances TRAIL-mediated apoptosis through up-regulation of DR5 by stabilization of mRNA and protein in cancer cells. Sci Rep 6: 22921, 2016.

50. Liu X, Chhipa RR, Nakano I and Dasgupta B: The AMPK inhibitor compound $\mathrm{C}$ is a potent AMPK-independent antiglioma agent. Mol Cancer Ther 13: 596-605, 2014.

51. ZinnahKMAandParkSY:Duloxetine enhances TRAIL-mediated apoptosis via AMPK-mediated Inhibition of autophagy flux in lung cancer cells. Anticancer Res 39: 6621-6633, 2019.

52. Yang Y, Hu L, Zheng H, Mao C, Hu W, Xiong K, Wang F and Liu C: Application and interpretation of current autophagy inhibitors and activators. Acta Pharmacol Sin 34: 625-635, 2013.

53. Hu X, Shi S, Wang H, Yu X, Wang Q, Jiang S, Ju D, Ye L and Feng M: Blocking autophagy improves the anti-tumor activity of afatinib in lung adenocarcinoma with activating EGFR mutations in vitro and in vivo. Sci Rep 7: 4559, 2017.

54. Lin YC, Lin JF, Wen SI, Yang SC, Tsai TF, Chen HE, Chou KY and Hwang TI: Chloroquine and hydroxychloroquine inhibit bladder cancer cell growth by targeting basal autophagy and enhancing apoptosis. Kaohsiung J Med Sci 33: 215-223, 2017.

This work is licensed under a Creative Commons Attribution-NonCommercial-NoDerivatives 4.0 International (CC BY-NC-ND 4.0) License. 